\title{
A Rare Parasitic Infection in Turkey: Schistosomiasis. Case Report
}

\section{Türkiyede Az Görülen Bir Parazitik Enfeksiyon: Şistozomiazis. Olgu Sunumu}

\author{
Berna AYTAÇ, İbrahim ŞEHITOĞLU
}

Department of Pathology, Uludağ University, Faculty of Medicine, BURSA, TURKEY

\begin{abstract}
Schistosomiasis is a water-borne parasitic disease. It is endemic in tropical and subtropical countries mainly in Africa and the eastern Mediterranean region. We report a case of a 37-year-old male who attended our hospital for terminal hematuria and irritative voiding symptoms. Schistosoma haematobium eggs were found in his urine sediment. He underwent transurethral resection of the bladder. Pathological study confirmed the existence of vesical schistosomiasis. S. haematobium cases are rarely seen in Turkey. Epidemiological and clinical significance of S. haematobium has been discussed.
\end{abstract}

Key Words: Schistosoma haematobium, Bladder

\section{ÖZ}

Şistozomiazis su yoluyla taşınan parazitik bir hastalıktır. Tropikal ve subtropikal ülkelerde başlıca Africa ve Doğu Akdeniz bölgelerinde endemiktir. Olgumuz 37 yaşında erkek bir hasta, terminal hematüri ve irritatif miksiyon semptomları ile hastanemize başvurdu. İdrar sedimentinde Schistosoma haematobium yumurtaları bulundu. Hastaya mesane transurethral rezeksiyonu uygulandı. Patolojik çalıșmada vezikal schistosomiasis varlığı doğrulandı. S. haematobium olguları Türkiye'de nadir görülmektedir ve bu nedenle $S$. haematobium'un epidemiyolojik ve klinik önemi tartışılmıştır.

Anahtar Sözcükler: Şistozoma hematobyum, Mesane

\section{INTRODUCTION}

Schistosomiasis is a water-borne parasitic disease that affects 200 million people and poses a threat to 600 million in more than 76 countries (1-3). It is endemic in tropical and subtropical countries mainly in Africa and the eastern Mediterranean region $(4,5)$. The infection can be seen nowadays in countries that the disease is not endemic because of the increase in travelling for tourism, business and education. In this report, we present a 37-year-old male who had urinary symptoms after a travel to Guinea and Mali for business.

\section{CASE REPORT}

A 37-year-old male visited mid-African countries 5 years ago for business. He stayed there for 6 months and started having symptoms 1 month after his return. He had intermittent, painless terminal hematuria and irritative voiding symptoms. He presented at a state hospital. His medical history was unremarkable. No significant findings were found at physical examination. Blood count showed eosinophilia (15.80\%), and renal function was normal. The urine sediment contained 65 erythrocytes and 8

(Turk Patoloji Derg 2012, 28:175-177)

Received : 30.11.2010 Accepted : 02.02.2011 leukocytes per field. Ultrasound revealed a solid mass with $2 \mathrm{~cm}$ in diameter located near the left ureteral orifice and irregularities in the bladder wall, with nodular thickening. He underwent a transurethral resection of the bladder. Helminthes eggs were seen in pathological examination and the patient was referred to our university hospital. He was evaluated in both pathology and microbiology departments. Cytological examination of urine was positive for Schistosoma haematobium eggs which had a delicate terminal spine that is wide at the base and rounded at the tip (Figure 1). Microscopic re-examination of the urinary bladder revealed chronic inflammation, including a prominent eosinophilia involving the mucosa and the full thickness of the lamina propria. Numerous helminth eggs were in clusters and centered within noncaseating granulomas and eosinophilic abscesses (Figure 2). Foreignbody giant cells engulfed many individual eggs.

Medical treatment was started with praziquantel (Bitricide ${ }^{\odot}$ ) $25 \mathrm{mg} / \mathrm{kg}$ in a single day, in two divided doses. The patient was called 3 months later for fresh urine examination for parasites, cytology, and bladder ultrasound.

Correspondence: Berna AYTAÇ

Department of Pathology, Uludağ University, Faculty of Medicine,

BURSA, TURKEY

E-mail: berbun@gmail.com Phone: +90 2242950000 


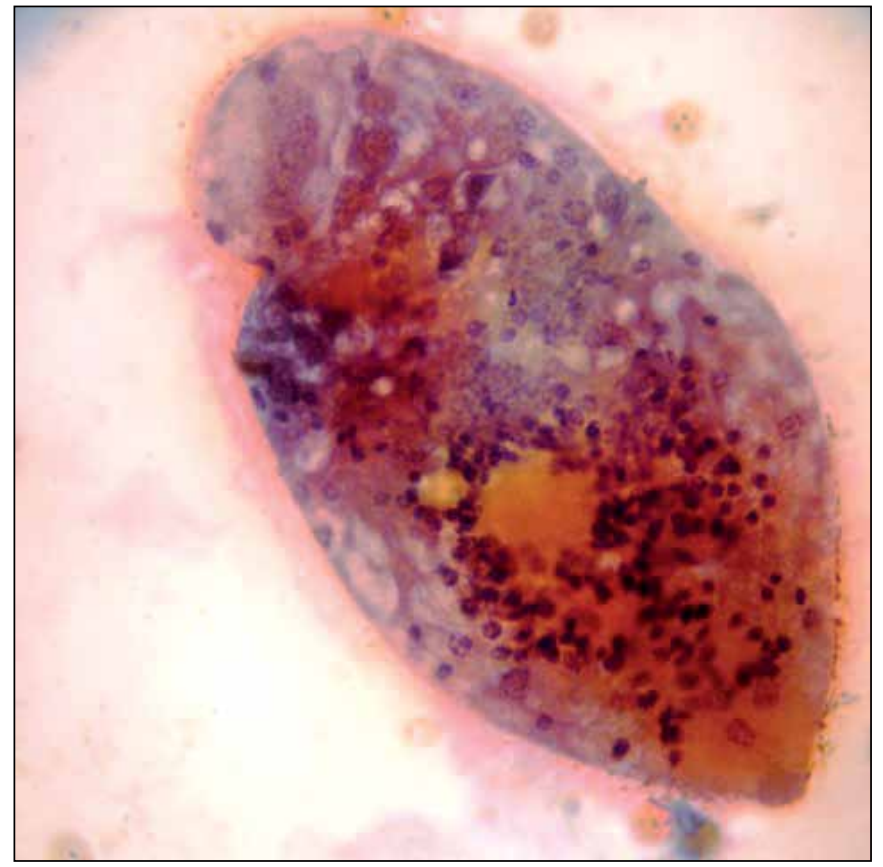

Figure 1: Schistosoma haematobium eggs which have a delicate terminal spine that is wide at the base and rounded at the tip in the urine (Giemsa, x1000).

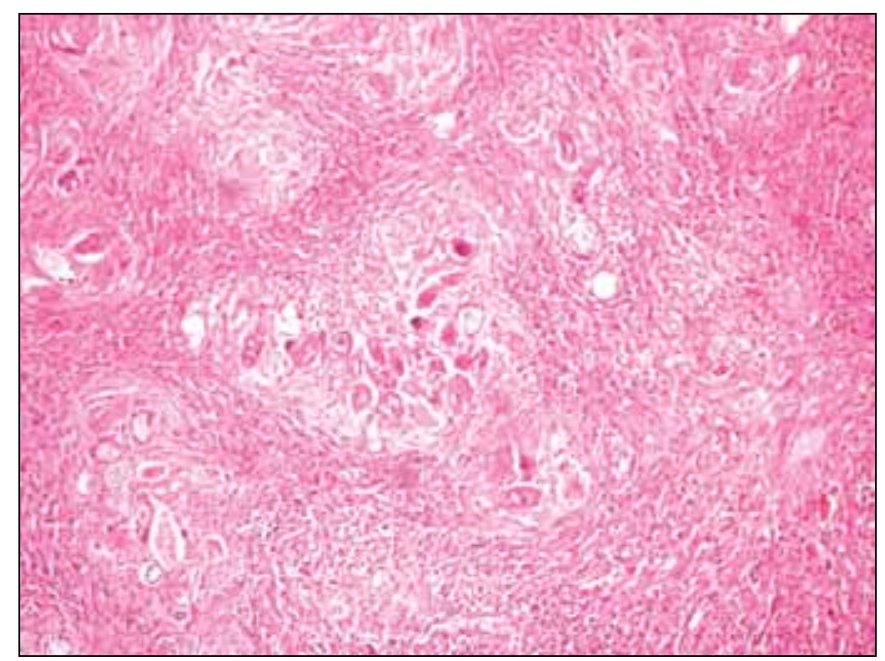

Figure 2: Numerous helminth eggs were in clusters and centered within noncaseating granulomas and eosinophilic abscesses in the lamina propria (H\&E, x200).

\section{DISCUSSION}

Schistosomiasis is a rare disease and remains an important health problem in many tropical countries. Its incidence is increasing in developed countries due to immigrant populations and tourists (6).

Ten species of schistosomes can infect humans, but genitourinary tract infection is caused by the Schistosoma haematobium species (5). It affects patients at a much younger age (mean 46.7 years) with males predominating over females 5.6 times (7).

Schistosomiasis enters the body by prolonged contact with infected water (4). The parasite is excreted from the body via urine and faeces into fresh water and the miracidia eventually infects its intermediate hosts, the fresh water snails, where they develop into cercariae $(1,4,5)$. The larvae (cercariae) are released from snails into water and penetrate human skin. It enters the subcutaneous tissues, then the blood stream, migrates to the lungs, then to the liver, and after 6 weeks, finally the mature worms mate. After maturation, the adult worm migrates into the mesenteric, perivesical venous plexuses and small, thinwalled vessels in the genitourinary system $(1,4,5,8)$. During the active phase, viable adult worms deposit eggs that induce a granulomatous response with the formation of polypoid lesions. The inflammation may manifest as wellcircumscribed granulomas or as a diffuse cellular infiltrate. Eosinophils and neutrophils usually predominate in the infiltrates, but plasma cells, lymphocytes, macrophages, and foreign-body giant cells are also present. During this time, eggs are excreted in urine. Adult worms may live for many years after the initial infection. After the death of the adult worms, no viable eggs remain in the urine and large numbers of calcified eggs can be found in the wall of the bladder and in other affected tissues $(1,2,4,5,8)$.

Clinical findings and outcomes are due to egg deposition, the inflammatory response and histopathological changes. They range from mild symptoms such as hematuria, leukocyturia, urinary tract complaints, tender abdomen, and supra-pubic tenderness to chronic iron deficiency and anemia, scarring and deformity of the ureters and bladder, chronic bacterial superinfection, severe damage of urinary tract organs, and ultimately renal failure $(2,4,5,9)$. The urinary bladder is the most affected area of the urogenital tract. The urethra, seminal vesicles, prostate gland, deferent ducts, epididymus, and testis are the other parts that may be affected. Such involvement causes prostatitis, urethral stenosis, and perineal pain (2).

The diagnosis strongly depends on the physician's awareness of the infection as a possible differential diagnosis. The disease should be suspected especially if there is a history of a travel to an endemic area and bathing in fresh water in such places, a history of a pruritic reaction on an exposed area of the skin after bathing, or an unexplained febrile illness several weeks after the travel (4).

A definitive diagnosis can only be made with evidence of viable eggs in the urine, stool, or biopsy specimens $(4,6)$. 
Visualization of eggs in the urine is the most sensitive and specific method for diagnosing active schistosomiasis $(4,2,10)$. S. haematobium eggs have a delicate terminal spine that is 2 to $3 \mu \mathrm{m}$ wide at the base, rounded at the tip, and 5 to $10 \mu \mathrm{m}$ long. Eggs may not be detected in the urine in chronic parasitation stages (2).

Radiographic studies are useful for the diagnosis in such cases. In the acute phase, nodular bladder wall thickening is observed at urography or cross-sectional imaging. The chronic phase is characterized by a contracted, fibrotic, thick-walled bladder with calcifications resulting from egg deposition along the mucosal membrane $(2,11)$. Immunoassay methods such as ELISA and RIA are sensitive but not specific and can be considered in early schistosomiasis when there is a strong suspicion. The serological immunofluorescence antibody test for the presence of specific antibodies has been found to be a sensitive marker of acute and chronic infection in some cases $(4,5,6)$. Evaluation of the eosinophil cationic protein in urine has been used as a sensitive method for detecting early urinary tract pathology $(4,5)$. The final diagnosis is based on the presence of granulomas and schistosoma eggs in the submucosa in bladder biopsies (2).

The medical treatment of urinary schistosomiasis is praziquantel, given orally as a single or divided dose of $40-$ $60 \mathrm{mg} / \mathrm{kg}(2,4,5,8,12)$. In adult schistosomes, praziquantel induces vesication, vacuolization, and disintegration of the tegument. General efforts to control schistosomiasis are focused on interruption of the life cycle at snail-human and human-snail transmission (4). The infection may recur in adults living in endemic areas as chronic reinfection produces incomplete immunity (4).

An important complication of chronic S. haematobium infection is bladder carcinoma. Squamous cell carcinoma is the most common histological type, since it arises on top of squamous metaplasia resulting from chronic cystitis. There is less common correlation with transitional cell carcinoma $(2,8,13,14)$. The majority of tumors present at an advanced stage. Most cases are muscle invasive, hence radical cystectomy is the main line of treatment $(3,12-14)$.

As Turkey is not an endemic country for schistosomiasis, a detailed medical history is mandatory for differential diagnosis of this parasitic infection. The clinician should suspect this clinical entity especially in patients with hematuria and a history of traveling to countries such as Asia and South Africa.

\section{REFERENCES}

1. Ekpo UF, Mafiana CF, Adeofun CO, Solarin AR, Idowu AB: Geographical information system and predictive risk maps of urinary schistosomiasis in Ogun State, Nigeria. BMC Infect Dis 2008, 8:74

2. Donate Moreno MJ, Pastor Navarro H, Giménez Bachs JM, Carrión López P, Segura Martín M, Salinas Sánchez AS, Virseda Rodríguez JA: Vesical schistosomiasis, case report and Spanish literature review. Actas Urol Esp 2006, 30:714-719

3. Mostafa MH, Sheweita SA, O'Connor PJ: Relationship between schistosomiasis and bladder cancer. Clin Microbiol Rev 1999, 12:97-111

4. Paul JF, Verma S, Berry K: Urinary schistosomiasis. Emerg Med J 2002, 19:483-484

5. Neal PM: Schistosomiasis an unusual cause of ureteral obstruction: a case history and perspective. Clin Med Res 2004, 2: 216-227

6. Mohammed AZ, Edino ST, Samaila AA: Surgical pathology of schistosomiasis. J Natl Med Assoc 2007, 99:570-574

7. Clements AC, Barnett AG, Nyandindi U, Lwambo NJ, Kihamia CM, Blair L: Age and gender effects in self-reported urinary schistosomiasis in Tanzania. Trop Med Int Health 2008, 13: 713-721

8. Neafie RC, Marty AM: Unusual infections in humans. Clin Microbiol Rev 1993, 6:34-56

9. Sousa-Figueiredo JC, Basáñez MG, Khamis IS, Garba A, Rollinson D, Stothard JR: Measuring morbidity associated with urinary schistosomiasis: assessing levels of excreted urine albumin and urinary tract pathologies. PLoS Negl Trop Dis 2009, 6:e526

10. Gyorkos TW, Ramsan M, Foum A, Khamis IS: Efficacy of new low-cost filtration device for recovering Schistosoma haematobium eggs from urine. J Clin Microbiol 2001, 39: 2681- 2682

11. Wong-You-Cheong JJ, Woodward PJ, Manning MA, Davis CJ: From the archives of the AFIP: Inflammatory and nonneoplastic bladder masses: radiologic-pathologic correlation. Radiographics 2006, 26:1847-1868

12. Palanca BA, Zaragozá QJ, Meseguer BJ, Pérez CF, Trullenque EF, Sempere PF: Bladder infection by schistosoma: an uncommon cause of haematuria. Actas Urol Esp 2008, 32:253-255

13. Gouda I, Mokhtar N, Bilal D, El-Bolkainy T, El-Bolkainy NM: Bilharziasis and bladder cancer: a time trend analysis of 9843 patients. J Egypt Natl Canc Inst 2007, 19:158-162

14. Bedwani R, Renganathan E, El Kwhsky F, Braga C, Abu Seif HH, Abul Azm T, Zaki A, Franceschi S, Boffetta P, La Vecchia $C$ : Schistosomiasis and the risk of bladder cancer in Alexandria, Egypt. Br J Cancer 1998, 77:1186- 1189 